\title{
REVIEW ARTICLE \\ SOIL FERTILITY MANAGEMENT, A TOOL FOR SUSTAINABLE DISEASE AND WEED CONTROL IN SUB-SAHARAN AFRICA: A REVIEW
}

\author{
A. M. SADDIQ1 ${ }^{*}$, A. IBRAHIM1, M. Y. JADA², A. M. TAHIR ${ }^{1}$, I. UMAR²
}

${ }^{1}$ Department of Soil Science, Modibbo Adama University of Technology, Yola, P.M.B. 2076, Yola Adamawa State, Nigeria

${ }^{2}$ Department of Crop Protection, Modibbo Adama University of Technology, Yola, P.M.B. 2076, Yola Adamawa State, Nigeria

\begin{abstract}
Agro-ecosystem health is built on habitat manipulation and fertility enhancement. Similarly, plant nutrient levels altered by fertilization practices can expose crop plants to pests. In addition, diseases, weeds and other pests are principal agricultural losses all over the world. This is particularly devastating particularly in the developing nations of Sub-Saharan Africa, especially Nigeria. Reduction in these losses will not only improve agricultural production but will enhance food security and economic well-being of society. Sole use of synthetic chemicals is economically not a viable option and does not encourage environmental sustainability while land expansion is equally elusive due to urbanization and different forms of development and not environmentally friendly. The most viable and practicable option is integration of different fertility management alternatives that could produce crops on a sustainable basis while ensuring the safety and sustainability of the environment. Integrated Soil Fertility Management (ISFM) has proved to be a promising approach to fertility management and sustainable environment. It could be adopted as it provides the needed nutrients for plants, reduce weeds and disease incidences while safeguarding the environment.
\end{abstract}

\section{INTRODUCTION}

Population is increasing all over the world and is expected to rise to over nine billion (9b) by 2050 and even higher by $2100[1,2]$. This calls for increased crop production to carter for these population and even the increasing livestock that may be required to carter for the protein requirement of the ever increasing population at least by $50 \%[2,3]$. Of tremendous importance is the production of food grains and vegetables that could be consumed and processed for livestock feeds. The sub-Saharan Africa threatened by myriad of soil and other environmental problems have great potential to increase agricultural productivity through integrating scientific and local knowhow [4]. Achieving this objective requires increased land for production and effective and sustainable fertility management, disease and weed control. However, expansion of land for agricultural production may seem elusive due to industrialization, urbanization; expansion in infrastructure like roads and railways, education and health centers. Furthermore, land expansion may translate in to deforestation with negative consequences on the environment. Similarly, disease and weed have been managed effectively in modern agriculture to a large extent through use of modern technologies particularly the use of pesticides. However, rising cost of global energy with consequences in chemical costs and appearance of resistance against chemicals by pests and diseases compounds the problem $[5,6]$. In addition, the agroecosystem is also threatened by the use of these chemicals and therefore questions productivity and sustainability of soils. Negative consequences of agro-chemicals to agroecosystems have severally been reported $[7,8]$. In addition, several herbicides have been reported to have influence on micronutrient availability $[9,10]$. This is particularly important in the Sub-Saharan African continent with dynamic unpredictable and disequilibrial climate $[11,12]$. Similarly, with changing climate, Africa remains one of the vulnerable continent with substantial number of its inhabitants dependent on agriculture for survival [13]. Thus, the most viable option is agroecosystem management through habitat manipulation, good and effective fertility management [14]. Intensive year round cultivation with effective fertility management and minimum use of agrochemicals could ensure sustainable environment and optimum yield.

In narrow perspective, soil fertility is the capacity of the soil to supply plant nutrients in the right amounts, time and proportions. However, broadly it is a complex term relating to the chemical, physical and biological soil attributes and processes in relation to environmental and crop condition. It is therefore governed by both internal and external factors. While internal factors are genetic and

\section{Received o7 October 2017; Accepted 18 December 2017}

*Corresponding Author

A. M. Saddiq

Department of Soil Science, Modibbo Adama University of Technology, Yola, P.M.B. 2076, Yola Adamawa State, Nigeria

Email: amuhammadsaddiq@mautech.edu.ng

(This article is open access and licensed under the terms of the Creative Commons Attribution License (http://creativecommons.org/licenses/by/4.o/) which permits unrestricted, use, distribution and reproduction in any medium, or format for any purpose, even commercially provided the work is properly cited. Attribution - You must give appropriate credit, provide a link to the license, and indicate if changes were made. 
cannot be manipulated on the field, the external are subject to manipulation to an extent. These includes climatic factors; precipitation. temperature solar radiation and relative humidity, edaphic factors; soil moisture, soil temperature soil mineral matter, soil organic matter and soil reaction, biotic factors; plants e. g competitive weeds and crop plants, symbiotic bacteria, animals eg earthworms, small and large animals, physiographic; geologic ie parent material, topography, anthropicmanagement. Thus, soil fertility is only a factor in the productivity of soils. Although fertility is only a factor in soil productivity, it has been shown to be the most limiting factor particularly in rainfed agricultural systems [15]. Importantly is the fact that nutrient imbalance, loss of soil carbon and biodiversity have been identified as some of the threat to soil function [16]. Nutritionally balanced plants have highest resistance and tolerance to pest, diseases and even weed infestation and the susceptibility of the plants to these increases as the nutrient concentrations deviate from the optimum [17].

At global scale fertility problems varied in relation to country's development and environmental conditions. And, in developed countries there are many problems from over production as well as environmental issues [18]. Contrary to this, in the developing world, agricultural production is constrained by low soil nutrients reserves, low organic matter contents and adverse soil conditions of aluminum toxicity, soil acidity, and phosphorus, ammonium and potassium fixation, poor soil structure and dense sub-surface layers, poor drainage and low water holding capacity [18]. Apart from these constraints, the tropical savanna soils are further constrained by low micronutrient levels as a consequence of low organic matter levels arising from their predominantly sandy nature and relatively low rainfall and high temperatures [19, 20, 21], and the use of primary nutrient elements as synthetic fertilizers on continuous basis compound the problems. In both scenarios the soils and crop plants are exposed to incidences of diseases and pest infestations [22].

\section{Disease and weed damage to crops}

Yield losses are incurred both on the farm (pre-harvest) and after harvest (post-harvest). The sources of the losses are diverse and multifaceted [23, 24]. The losses could be due negative effects of either biotic or abiotic factors. Global losses have been estimated to be within 35-70 \% [25]. Out of these, a substantial percentage of the losses are due to pests comprising of animal pests, birds, rodents, slug and snails, mites, insects and nematodes; plant pathogens: bacteria, fungi, viruses and chromista, and weeds with losses of 34,18 , and $16 \%$ for weeds, animal pests and microbial diseases respectively [25). Losses due to weeds depend on crop type, cropping system, location and species of weeds [23]. Global potential crop losses due to pests and diseases was estimated to be $40.3,37.4,31.2$, 28.8 and 28.2 \% for potatoes, rice maize, cotton and wheat respectively [25]. High losses particularly in the staple cereals could further endanger the threat of food security in the region. Potential losses due to weed was estimated at $34 \%$ while animal and pathogens were estimated at 18 and $16 \%$ respectively [25]. Reduction of nutrient availability, uptake, distribution and utilization by crops are consequences of plant diseases, thus limits improved production efficiency and crop quality [26, 27]. Disease development occurs as a consequential interaction of susceptible hosts, virulent pathogen and a favorable environment [28]. Importantly also, is the fact that global warming and changing climate increase disease incidence with rise in temperature. Temperature rise by a unit increased severity of terminal disease development [29]. It was reported that in every $1{ }^{\circ} \mathrm{C}$ rise above $30{ }^{\circ} \mathrm{C}$ for maize crop under stressed condition, there is an accompanied 1.7 $\%$ reduction in yield [30]. Strategized agro-system manipulations through habitat modification and fertility management have been identified as a key factor in not only reducing the negative effects of diseases and pests but also produce optimum yield. In addition, sustainability of the environment is ensured and current threat to nutrient imbalances is curtailed $[31,16]$. Agroforestry, crop rotation, mulching, green manuring and use of organic manures, mineral fertilizers, and integrated soil fertility management have apart from enhancing soil fertility reduced yield losses due crop diseases and pests.

\section{Fertility management, diseases and weed control}

\section{Agroforestry}

Agroforestry has been an important element in agricultural production due not only to its high productivity compared to monocultural systems but due to its complementarity in resource capture through deeper roots accessing both water and nutrients and recycling through leaf fall [31, 32, 33]. Carbon sequestration, biodiversity conservation and soil enrichment are also benefits of agroforestry system [34]. $7 \mathrm{~kg} \mathrm{Nkg}^{-1} \mathrm{yr}^{-1}$ have been reported as nitrogen release from litter fall [35]. Apart from nutrient recycling, pest can be regulated by agroforestry through providing sources of adult food (e. g flowers) site for mating [36], thus reducing the negative effects of pests. It has also been identified long before now as one of the most effective means of nematodes control, parasitic fungi, many other pests and diseases in all agricultural systems particularly in tropical Africa [37]. In addition, although most agroforestry system reduces crop yield, there is always a give and take relationship with environmental sustainability [38].

\section{Mulching}

Mulch has successfully been used not only to improve and sustain soil fertility but also reduce pests, disease and weed infestation. It has also been a good moderator of the agroecology. Mulches, apart from regulating nutrient levels, it had been shown to hamper weed emergence particularly at the beginning of season [39, 40]. Polyethylene mulch have been reported to effectively control phythopthora infestans in tomato, in fact, more effectively compared to use of fungicides [41]. Similarly, pythopthora infestans in leaf infection was drastically reduced through increased systemic resistance by arbuscular mycorrhizal fungi [42]. Nemades (Pratylenchs penetrans) in apple plantation were successfully reduced by the use of Newspaper mulch [43]. In a study of alternative weed control using allelopathic effect of natural benzoxazinoids from rye mulch, and the use of rye mulch to control weed reduce herbicide use and enhance soil health was confirmed [44], thus reducing the negative effects of herbicide on the agroecosystem. Generally, crop pests are effectively reduced naturally through mulches $[42,43]$.

\section{Green Manuring/Cover crops and use of organic manures}

Green manuring is a method of soil fertility restoration in which fresh plant material either in situ or brought from a long distance is turned under to maintain soil carbon pool [45]. There are different sources of green manure crops; grain legumes or perennial woody multipurpose legume 
trees [45]. The grain legumes include but not restricted to pigean pea (Cajanus cajan), green gram (Vigna radiata), Soybean (Glycine max), groundnut (Arachis hypogea) common beans (Phaseolus Vulgaris) [46]. The woody perennial legume trees include Kassod tree (Cassia siamea), Subabul tree (Leucaena leucocephala), Glicidia tree (Glinicidia sepium). The use of green manuring in soil fertility restoration and maintenance has been reported in Asia [45], and researches have confirmed its multiple advantages [47-45]. Green manuring improves fertility through increasing microbial activities and increase the nutrient supplying capacity of soils. It moderates soil structure; reduce soil erosion, control weeds and soil borne diseases [50, 47, 51, 49, 52, 53]. Bacterial and Fungal infections, pathogenic effects of nematodes have also been proved to be remedied by green manuring [48, 54-61]. Similar to green manuring, organic manures have been proved to improve soil fertility, reduce disease incidence, control weed and sustain the environment $[62,63]$.

\section{Mineral fertilizers}

Mineral or synthetic fertilizers have profound effects on germination, growth and yield of crops and reduction in pests and diseases $[64,65]$. In a study effect of inorganic fertilizer on aphids' abundance, [66] reported variable effects of mineral fertilizer on mites and aphids' population on selected crops and indicated increased infestation in response to mineral fertilization. However, good fertilizer management provides competitive advantage to growing crops, reduces weed interference and competition [67] and thus, have direct impact on weed control strategies [64-69].

\section{Crop rotation}

The cultivation of different crops with different characteristics on the same field for successive years and following a previously established sequence is referred to as crop rotation [70, 71]. Effective pests and disease control have severally been achieved from rotation of crop combination [72]. The crops used in rotation system depend on geographical location, climate and soil type [70, 73]. Crop rotation is practiced in both developed and developing economies of the world; however, differ in emphasis in terms of objectives. In conventional crop rotation, emphasis is on the control of stubborn weeds, diseases and pests while in dryland systems of agriculture, the emphasis is on water conservation, minimization of salinity and soil fertility improvement [70]. However, both are usually achieved with proper rotational sequence of crops [70, 67] suggested integration of enhanced soil fertility management through use of mineral fertilizers, cover crops, green manures, mulching, compost and rotations and enhanced pest regulation through crop diversity, good cultural practices, pesticides and habitat modification for a healthy crop and agro-ecosystem. Crop rotation is the fulcrum of all sustainable farming systems and gives the most effective and efficient indirect method of controlling or minimizing weeds, diseases and pest problems while maintaining and sustaining soil fertility $[70,71]$. Lower pest pressure has been reported in several literatures and this has been attributed to rotation and is mediated by improved soil fertility [70-78].

\section{Plant nutrition, disease and pests control}

Plant nutrition is one of the most effective strategies of controlling diseases in an agricultural setting. The use pesticides in controlling pests have severally been questioned due to environmental sustainability and safety [79]. Pesticides; fungicides (toxic to fungus), insecticides (toxic to insects), nematicides (toxic to nematodes), and weedicides (toxic to weed) when applied to the environment upset the ecological balance and destroy micro-flora and fauna [80]. Fertilization or soil manipulation to influence nutrient availability and control diseases has severally been reported in many excellent reviews $[81-86,65]$. Sound defense mechanism of crop plants with balanced nutrition due adequate supply of plant nutrients has been shown to be an insurance to weed, pests and disease control [79]. Susceptibility of the host to various pathogens is directly a function of the strength of the host; the plant system and the environment [87]. Nutritionally balanced plants exhibit high defense system and since multiplication, penetration and distribution of the different disease causal pathogens is through weaker cell walls, the chances of infection or damage is substantially reduced [79]. In a study of the effects of $\mathrm{N}$ and $\mathrm{K}$ mineral fertilizer application on levels of severity of disease caused by parasites, $[66,65]$ indicated that high nitrogen levels reduced the severity of facultative parasites while high potassium levels reduced the severity of both obligate and facultative parasites [66]. In another study of nutrient fertilization on disease incidence, [88] indicated that depending on the form, time and method of fertilizer $\mathrm{N}$ applied, 168 of 1, 180 sampled decreased disease incidence due to fertilizer $\mathrm{N}$ application. Similarly, potassium supplies reduced disease incidence by $12 \%$ of the total cases [88]. The same thing applies to the other secondary and micronutrients [88]. Compost has been shown to be used effectively to achieve reduce disease infestation in different crops [89]. [64, 65] further reported that the incidence of Erysiphe graminis (powdery mildew in Barley/Wheat crop by $95 \%$ using 1:1 ratio soil: compost mix was reduced. Similarly, pea germination was significantly facilitated by soaking the seed in compost extract $[64,65,89]$. In a field infested by Rhizactonia spp, the infestation was reduced by $80 \%$ in which highest compost rates of 72 ton/acre) were applied, $40 \%$ where intermediate rates were applied and highest grain yield was achieved with plot with highest compost rates [81]. Similar results were achieved in controlling phythoptora sp in pepper (89). Clover tiredness and increased yield in Alfalfa was also achieved using compost [81]. Disease suppression was apart from other factors linked to soil fertility levels and nature of the soil itself and adding compost into the soil induces disease resistance in many plants [90, 91]. Earlier, [29] has indicated that the ability of a crop to resist or tolerate insect pests and diseases is tied to optimal physical, chemical and biological soil attributes and any form of farm practices causes nutrition imbalances can lower pests and disease resistance [92]

In a review on defense system of plants against diseases as affected by primary and secondary nutrient elements, [79] indicated that the susceptibility of plants to diseases of fungus, Bacteria, viral and other soil-borne diseases can directly be linked to balance fertilization and nutrition of plants. Nutrients move within the cells to the apoplast through leakage of thinner and weaker cell walls and fungal spore's germination is often facilitated by these weaker leakages when there is $\mathrm{K}$ deficiency [79]. Imbalances of nutrients particularly of nitrogen, potassium and calcium in the plant system expose them to attack by fungal diseases [79]. This is similar in bacterial, viral and other soil-borne diseases where nutrient imbalances exist [79]. Thus, although disease resistance of plants is 
genetically controlled, its susceptibility to diseases is directly associated with imbalances in nutritional status of plants $[66,65,90]$. Different studies $[65,90,93]$ indicated that providing nutrient sufficiency remains the principal component of full expression of genetic resistance. Crop sequence/rotation, organic amendments, soil $\mathrm{pH}$ adjustments, tillage and irrigation management influences weed and disease control through nutrient interactions $[79,93,94]$. The entire essential nutrient element in one way or the other influence the incidence or severity of some diseases [64, 65, 90, 93, 94].

\section{Integrated soil fertility management (ISFM)}

Global intensification of agriculture with use of high yielding crop varieties (HYV), excessive use of mineral fertilizers and pesticides after the World War II and land expansion was said to be the root course of soil degradation and pest's resistance $[73,95,96,97,98,99$, 100, 101, 102]. Agrochemicals generally have undesirable effects on the environment; bio magnification, long halflives, destruction of non-target organisms and eutrophication of adjacent fields [73, 100-102]. Environmental manipulation through fertility management could moderate the interaction of the host plant, the pathogens and the environment as well as reduce weeds, pests and disease incidences, thus safe guarding the ecosystem $[47,79,80,84,89,90,91,98,102$, 103]. Integrated soil fertility management has proved to be an effective technology in many countries due to its use of local materials and cultural practices [104-109] and has effectively improved soil fertility and reduced weed and diseases infestation [106-109]. However, level of genetic resistance, nutrient availability relative to plant requirements, form and stability of nutrient applied or available, rate, time and method of nutrient applied, nutrient ratios and associated ions as well as integrating fertilization with other cultural practices are imperative in sustainable soil management. It is envisaged that in future more biodiverse agricultural systems may be more productive than the monocultures [73, 109].

\section{CONCLUSION}

Holistic approach is required to sustainably produce crops and safeguard the ecosystem due to the complexity of various interacting factors. Competing demands of resources made it pertinent to have a rethink on sustainability of both production and the environment particularly with global geometric increase in population in which the African continent is said to be most affected on its negative consequences. Improved high crop yielding varieties (HYV), pesticides and heavy doses of mineral fertilizers have been advocated and used for increased crop production globally including Nigeria. However, small farm holding farming systems dominant in Africa with the poor resource base of the farmer and negative consequences of using both heavy doses of mineral fertilizers and pesticides where feasible put the sustainability of both production and environment into question. Integrated soil fertility management which recognizes the use of improved germplasm, mineral fertilizers, organic materials sourced in cognizance of the local environment and management practices may be a viable option for controlling weed and diseases as well as sustaining fertility, environment and production of crops.

\section{REFERENCES}

1. FAO (2009). Global Agriculture Towards 2050, FAO, Rome, October, 2009

2. Popp, J. S., K. Peto, and J. Nagy (2013). Pesticide productivity and food security: A review. Agron. Sustain. Dev. 33:243-255, DOI10.1007/s135930120105-X

3. Chakroborty, C. and A. C. Newton (2011). Climate change, plant disease and food security: An overview. Plant Pathology, 60:2-14,DOi: 10.1111/j.13653059.2010.02411. $x$

4. UNEP (2014). Assessing Global Land Use: Balancing consumption with sustainable supply. A report of the working group on land and soils of the international resource panel, Bringezu, S., Schutz, H., Pengue, W. O., Brien, M., Garcia, F., Sims, R., Harwrth, R., Kauppi, L., Swilling. M and Harrick, J. (Eds).

5. Pretty, J. and Weibel, H. (2004). Paying the Price: The Full Cost of Pesticides. Chapter 3, In: the Pesticide Detox: Solutions to Safe Agriculture (J. Pretty, Editor) Earthscan Publications Ltd, London. Published in association With the United Nations Food and Agricultural Organisations.

6. Nuppenau, Ernst-August (2011). Linking Crop Rotation and Fertility Management by a transition Matrix: Spatial and Dynamic Aspects in programming of ecosystem service, Paper Presented at the EAAE 2011 Congress Change and Uncertainty Challenges for Agriculture, Food and Natural resources, August $30^{\text {th }}$ September 2, 2011, ETH zurich, Zurich, Switzerland

7. Hornby, D.; Bateman, G. L.; Gutteridge, R. J.; Lucas, P., Osbourn, A. E.; Ward, E; Yarham, D. J. (1998). Take-all disease in cereals: A regional perspective. $\mathrm{CAB}$ International Wallingford, UK

8. Mekwatanakarn, P., Sivasithamparam, K (1987). Effect of certain herbicides on soil microbial populations and their influence on saprophytic growth in soil and pathogenicicity of the take-all fungus. Biol. Fert. Soils 5, 175-180

9. Evans, I. R., Solberg, E., Huber, D. M. (2007). Cpper and plant disease. In: Datnoff, L. E., Elmer, W. H., Huber, D. M. (eds), Mineral Nutrition and Plant Disease. APS Press St. Poul, MN, pp 177-188

10. Huber, D. M.; Leuck, J. O.; Smith, W. C.; Chrismas, E. P. (2004). Induced manganese deficiency in GM soybeans. In Northecentral Fert. Ext. Conf., Desmoines, 1A, Nov.2004

11. Warren, A. (2005). The policy implication of Sahelian change. Journal of Arid Environments 63:660-670

12. Niang, I., Ruppel, O. O., Abdrabo, M. A. Essel, A., Lennard, C., Padgham, J. Urquhart, P. (2014). Africa. In V. R. Barros et al. (Eds). Impacts

13. Phiiri, G. K., Egeru, A., Ekwama, A. (2016). Climate change and agricultural nexus in Sub-Saharan Africa. The agonizing reality for smallholder farmers. Int. J. Curr. Res. Rev. 8:57-64

14. Altieri, M. A. Ponti, L. and Nicholls, C. I. (2012). Soil fertility, biodiversity and pest management. In; Biodiversity and Insect Pests, William, E. Synder, John Wiley and Sons. Pp72-84

15. Lal, R. (2002). Soil Management in the Developing Countries. Soil Sc. 165:57-72

16. Montanarella, L., Pennock, D. J., Mckenzie, N., Badraoui, M., Chude, V., Batista, I., Mamo, T., Yemefack, M., Aulakh, M. K., Yagi, K., Hong, S. Y., Vijarnsorn, P. Zhang, G., Arrouys, D., Black, H., Krasilnikov, P., Sobocka, J., Alegre, J. Henriquez, C. 
R., Mendonca, Santos, M. L., Taboada, M., EspinosaVictor, D., Alshankiti, A., Alvipanah, S. K., ElMustapha ElSheik, A. Hampel, J. Arbesian, M. C., Nachtergaele, F. and Vargas, R. (2016) Soils are Under Threat Soil; 2,79-82. www. soil. journal. net/2/79/2016/doi.10.5194/soil-2-79-2016

17. Spann, T. M., Schumann, A. W. (2010) Mineral Nutrition Contributes to plant Diseases and Pest resistence. Serie No. HS1181, horticultural sciences Department, UF/IFAS Extension, University of Florida, Gainesville, FL.

18. Sanchez, P. A.; K. D. Shepherd; M. J. Soule; F. M. Place; R. J. Buresh, A. M. Izac, A. U. Mokwunye; F. R. Kwesiga, C. G. Ndiritu and P. L. Woomer (1997). Soil Fertility Repleshment in Africa: An Investment in Natural Resource Capital. In American Society and Soil Science Society of America, 677, Madison, USA. Replenishing Soil Fertility in Africa. SSSA Special Publication no 51

19. Jones, M. J. (1973). The Organic matter content of the savanna soils of West Africa. Samaru Research Bulletin 186

20. Jones, M. J. and A. Wild (1975). Soils of the West African Savanna: The maintenance and improvement of their fertility. Technical Communication No 55 of the Commonwealth of soils Harpenden CAB Pp 246

21. Singh, L. (1997). Soil Fertility Management: The key to high crop productivity. Abubakar Tafawa Balewa University, Bauchi. Inaugural Lecture Series No 6

22. Kotschi, J. (2013). A soiled Reputation: Adverse impacts of mineral fertilizers in tropical agriculture. Heinrich, Boll stiftung (Heinrich Boll Foundation), WWF Germany

23. Swinton, S. M., Buhler, D. D., Forecella, F., Gunsollus, J. L., King, R. P. (1994). Estimation of crop yield loss due to interference by multiple weed species. Weed Sci. 42:103-109

24. Boydston, R. A., Mojtahedi, H., Crosslin, J. M., Brown, C. R., Anderson, T. (2008). Effect of hairy nightshade (Solanum sarrachoides) presence on potatao nematodes disease and insect pests. Weed Sci. 56:151154

25. Oerke, E. C. (2006). Crop losses to pest. Journal of Agricultural Science, 144, 31-43

26. Huber, D. M. and Graham, R. D. (1999). The Role of Nutrition in Crop Resistance and Tolerance to Disease, In: rengel, Z. (Ed). Mineral Nutrition of Crop Plants, fundamental mechanisms and implication, Food Product Press, New York, pp 205-226

27. Dordas, C. (2009). Role of Nutrients in Controlling Plant Diseases in Sistainable Agriculture: A Review, In: Lichtfouse, E. (Eds), Sustainable Agriculture, DOI. 10.1007/979-481-2666-8_28, Sringer

28. Ghini, R., Hamada, E., Beltiol, W. (2008). Climate change and plant diseases. Scientia Agricola 65:98107

29. Aggrawal, P. K. (2009). Rainfed Agriculture: Unlocking the Potential. CAB International, 2009

30. Chijoke, O. Y., Haile, Mekbib, Waschkeit (2011). Implication of climate on crop yield and food accessibility in sub-saharan Africa. Univisitatbonn, Interdisplinary Term Paper, ZEF Doctoral Studies Programm retrieved 22/092017. PDF

31. Kuruppuarachchi, K. A. J. M., Seneviratne, G., Madurapperuma, B. D. (2016). Carbon sequestration tropical forest stands: its control of plant, soil and climate factors, Doi.10.4236/ojf.2016.62006
32. Sinclair, F. L., W. R. Eason and J. Hooker (2009). Understanding and Management of Interactions, In: Bulletin 122, Agroforestry in the UK, A. M. Hislop and J. Claridge (Ed). Forestry commission, Edinburgh

33. Smith, P. and Olesen, J. E. (2010). Synagies between the mitigation of adaptation to climate change in agriculture, Journal of Agricultural Science, Cambridge 148:543-552

34. Jose, S.(2009). Agroforestry for ecosystem services and environment benefits: An Overview. Agroforest Syst. 76:1-10.

35. Thevathasan, N. V. and A. M. Gordon (2004). Ecology of tree intercropping systems in the North temperate region: Experiences from southern Ontorio, Canada. Agroforestry systems 61:257-268

36. Stamps, W. T. and M. J. Linit (1998). Plant Diversity and arthropod communities: Implication for Temperate Agroforestry. Agroforestry Systems 39:7389

37. Bulluck, D. G. (1992). Crop Rotation. Crit. Rev. Plant Sci. 11:309-326

38. Pandey, D. N. (2007). Multifunctional agrosystems in India, Current Science 9:455-463

39. Petrivkovszki, R., Korosi, K., Nagy, P., Simon, B., Zalai, M. and Toth, F. (2016). Effect of Leaf Litter Mulching on the Pest of Tomato, Journal of Agricultural Environmental Sciences 3:35-46

40. Bhardwaj, R. L. (2013). Effect of mulching on crop production under rainfed condition: A Review. Agric. Reviews, 34:188-197

41. Shtienberg, D., Elad, Y. Bornstein, M., Ziv, G., Grava, A. and Cohen, S. (2010). Polythene mulch modifies greenhouse microclimate and reduces infection of phytophthora infestans in tomato and Pseudoperonospera cubensis in cucumber. Disease Control and Management 100: 97-104

42. Gallou, A., Mosquera, H., P. L., Sylvie, Cranenbrouck, S., Suarez, J. P., Declerck, S. (2011). Mycorrhiza induced resistence in potato plantlets challenged by phytophthora infestans. Physiological and molecular plant pathology 76:20-26.

43. Forge, T. A., Hogue, E. J., Neilsen, G., Neilsen, D. (2008). Organic mulches alter nematode communities, root growth and fluxes of phosphorus in the root zone of apple. Applied Soil Ecology 39:15-22

44. Tabaglio, V. C., Gavazzi, M., Schulz, and Morocco, A. (2008). Alternative weed control using allelopathic effect of natural benzaxozinoids from rye mulch. Agronomy for sustainable development. Springer verlag/EDP Science/INGRA, 2008, 28 , pp397-401 http://www. agronomy-journal. org.

45. Kumar, R., G. Mahajan, S. Srivastava and A. Sinha (2014). Green Manuring: A Boon for sustainable Agriculture and Pest Management: A Review, Agri. Review, 35: 196-206

46. Cobley, L. S. (1976). An Introduction to The Botany of Tropical Crops $2^{\text {nd }}$ Edition, Longman pp 71-10

47. Blackshaw, R. E., J. R. Moyer, R. C. Doran and A. L. Boswell (2001). Yellow Sweetclover, Green Manure, and its Residues Effectively suppress Weeds During Fallow. Weed Sci. 49:406-413

48. Larkin, R. P. and T. S. Griffen (2007). Control of Soilborne potato disease using Brassica green manures. Crop Prot. 26:1067-1077

49. Sinha, A., R. Kumar, D. Kamil, P. Kapur (2009). Release of Nitrogen, Phosphorus and Potassium from decomposing Crotalaria juncea $\mathrm{L}$. in relation to 
Different Climatic Factors. Environ. Ecol. 27(4B):2077-2081

50. Schumann, R. A., J. H. Mayer, and R. Van Antwerpen (2000). A Review of green Manuring in Sugar Cane Production. Proc. South Africa Sugar Techol. Assess. 74:93-100.

51. Eriksen, J. (2005). Gross Sulphur MineralizationImmobilization Turnover in Soil Amended with Plant Residues. Soil Biol. Biochem. 37:2216-2224

52. Kumar, R. (2010). Studies on Decomposing Fungi of Sesbania aculeate L. In: Soil and its effects on Soil Borne Plant Pathogens, Ph. D. Thesis. Banaras Hindu University, Varanasi

53. Egodawatta, W. C. P., U. R. Sangaakkara, D. B. Wijesinghe and P. Stamp (2011). Impact of green manure on productivity pattern of home gardens and fields in tropical dry climate. Agric. Res. 22:172-182

54. Johnson, A. W., A. M. Golden, D. L. Auld and D. R. Sumner (1992). Effects of Rapeseed and Vetch as Green Manure Crops and Follow on Nematodes and Soil-borne Pathogens, J. Nematol 24:117-126

55. Cardoso, S. C., A. C. E. Soares, A. Brito, S. L. dos, E. E. Laranjeira, C. A, S. Ledo, A. P. Santos (2006). Control of Tomato Bacterial Wilt Through the Incoration of aerial Part of Pigeon Pea and Crotalaria to Soil. Summa Phytopathologica 32:27-33

56. Sexton, P. A., A. Plant, S. B. Johnson, J Jr. Jemison (2007). Effect of a Mustard Green Manure on Potato Yield and Disease incidence in Rainfed Environment. Online. Crop Management doi.10.1094/CM-20070122-02-RS.

57. Kinkel, L. L., Stromberg, K. D. J. M. Flor and E. Wiggins (2001). Green manures influence pathogen inhibitory potential of indigenous antagonist cummunities in soil. Phytopathol 91:S49

58. Wiggins, B. E. and Kinkel, L. L. (2007). Green manures and crop sequences influence on potato disease and pathogen inhibitory activity of indigenous strepmycetes. Phytopathol 95:178-185

59. Kamil, D., R. Kumar, and A. Sinha (2009). Effect of Green Manuring of Crotalaria juncea L. on some Soilborne Pathogens. Indian Phytopath. 62:304-309

6o. Pankeerathan, K., G. Mukinthan, and N. Tharshani (2009). Eco-Friendly Managent of Root-knot nematode Meloidogyne incognita (Kofid and White) Chitwood Using Different Green Leaf Manures on tomato under Field Conditions. American-Eurasian J. Agric. Environ. Sci. 6:494-497

61. Agbenin, N. O. (2011). Impact of Soil Health Management Practices on Soil-borne Pathogens, Nematodes and Root Diseases of Vegetable Crops. Appl. Soil Ecol. 15:37-47

62. Ibeawuchi, I. I., Iwuanyanwu, U. P., Nze, E. O.; Olejeme, O. C. and Ihejirika, G. O. (2015). Mulches and organic manures as renewable energy sources for sustainable farming. Journal of Natural Sciences Research Vol. No 2, 2015

63. Simarmata, M., Sitannggang, C. D. and DJamalah (2015). The Shifting of weed composition and biomass production in sweetcorn field treated with organic composts and chemical weed control AGRIVITA Vol 37 No 3

64. Marschner, H. (1986). Mineral Nutrition of Higher Plants. Academic Press, London

65. Marschener, H. (1995). Mineral Nutrition of Higher Plants, Second Edition, UK; Academic Press.

66. Luna, J. M. (1988). Influence of soil fertility practices on agricultural pests. In: Proceedings of the Sixth
International Conference of IFOAM on global Perspective on Agro-ecology and Sustainable agricultural Systems, Santa Cruz, CA, pp 589-600

67. Bajwa, A. A., Ehsanullah, Anjum, S. A., Nafees, W. Tanveer, M., Saeed, H. S. (2014). Impact of fertilizer use on weed management in conservation agriculture: A Review. Pakistan J. Agric. Res. Vol. 27. 69-78.

68. Mesbah, A. O. and Miller, SD (1999). Fertilizer placement affects jointed goat grass (Aegilops cylindrica) competition in winter wheat (Triticum aestivum L.). Weed Technol 13:374-377

69. Cathcart, R. J. and Swanton, C. J. (2003). Nitrogen management will influence threshold values of green foxtail (Setaria viridis) in corn. Weed Sci. 51:975-986

70. Ball, B. C., I. Bingham, R. M. Rees, C. A. Watson, and A. Litterrick (2005). The role of crop rotations in determining soil structure and crop growth conditions, Canadian Journal of Soil Science www. nrcresearchpress. com197.211.59.143, o825/17

71. FAO, (2011). http: faostat. fao. org accessed, Nov.2017

72. Doohan, D., Wilson, Canales, E., Parker, J. (2010). Investigating the dimension of weed management: New tools of the trade. Weed Sci. 58:503-510

73. Warren, J., Lawson, C. and Belcher, K. (2008). The Agri-Environment Cambridge University Press, UK. Pp 224

74. Shiningayamwe, E. (2012). Crop rotation as a soil fertility improvement strategy using different Legumes on a pearlmillet yield. AGRICOLA, 2012:4044

75. Altieri, M. A. and Nicholls, C. I. (1990). Biodiversity, ecosystem functions and insect pest management in agricultural systems. In Collin, W. Qualset, C. O. (Edts), Biodiversity in Agro-ecosystem. CRC Press, Boca Raton, pp69-84

76. Altieri, M. A.; Schmidt, L. L. and Montalba, R. (1998). Assessing the effects of agroecological soil management practices on broccoli insect pest populations. Biodynamics 218:23-26

77. Phelan, P. L., J. F. Mason, and B. R. Stinner. 1995. Soil-fertility management and host preference by European corn borer, Ostrinia nubilalis (Hübner), on Zea mays L.: A comparison of organic and conventional chemical farming. Agriculture, Ecosystems and Environment 56:1-8. (Available online at: http://dx. doi. org/10.1016/0167880900640-0 (verified 11 March 2010).

78. Phelan, P. L., K. H. Norris, and J. F. Mason. 1996. Soil-management history and host preference by Ostrinia nubilalis: Evidence for plant mineral balance mediating insect-plant interactions. Environmental Entomology 25:1329-1336.

79. Bhaduri, D., Rakshit, R and Chakraborty, K. (2014). Primary and Secondary Nutrients-a Boon to Defense System against Plant Diseases. International Journal of Bio-resource and Stress Management 5 : 461-466, Doi: 10.5958/0976-4038.2014.00597.1

80. Mishra, P. C. (2001). Soil Pollution and Soil Organisms. ASHISH Publishing House, New Delhi Pp17-43

81. Huber, D. M. and R. D. Watson (1974). Nitrogen form and plant disease. Annual Review of Phytopathology 12:139-165

82. Huber, D. M. (1980). The role of mineral nutrition in defense. In Plant Disease, An Advanced Treatise, Volume 3, How Plants Defend Themselves, Eds, J. G. 
Horsfall and E. B. Cowling. New York: Academic Press, pp, 381-406

83. Huber, D. M. (1989). Introduction. In Soilborne Plant Pathogens: Management of Dieases with Macro and Microelements, Ed, A. W. Engelhard. St. Paul, MN: APS Press, pp1-8

84. Huber, D. M. (1991). The Use of fertilizers and organic amendments in the control plant disease. In Handbook of Pest Management in Agriculture, Volume 1, Second Edition, Ed. D. Pimentel. Boca raton, FL: CRC Press, pp.405-494

85. Engelhard, A. W., Ed (1989). Soilborne Plant Pathogens: Management of Diseases with Macro and Micronutrients. St. Paul, MN: APS Press

86. Graham, R. D. and M. J. Webb (1991). Micronutrients and Disease resistance and tolerance in plants. In Micronutrient in Agriculture, second Edition, Eds. J. J. Mortvedt, F. R. Cox, L. M. Shuman, and R. M. Welch. Madison, WI: Soil Science Society of America, pp, 329-370

87. Johal, G. S. and Huber, D. M. (2009). Glyphosate effects on disease of plnats. European Journal of Agronomy 31:144-152

88. Huber D. M. and Graham, R. D. (2002). The Role of Nutrition in Crop Resistance and Tolerance to Diseases, In: Mineral Nutrition of Crops; Fundamental Mechanisms and Implications; Zdenko Rengel (Edt). pp399

89. Singh, S. S. (2004). Soil Fertility and Nutrient Management,Kalyani Publishers, New Delhi, India pp253

90. Rengel, Z. (Edt) (2002). Mineral Nutrition of Crops: Fundamental Mechanisms and Implication CBS Publishers and Distributors pp399

91. Kheyrodin, H. (2011). Crop Rotations for Managing Soil-borne Plant Diseases, African Journal of Food Science and Technology Vol. 2:001-009

92. Magdoff, F., van Es, H. (2000). Building Soils for Better Crops. SARE, Washington, DC

93. Huber, D. M. and S. Haneklaus (2007). Managing Nutrition to Control Plant Diseases Landbauforschung Volkenrode $4: 313-322$

94. Datnoff, L. E., Raid, R. N., Snyder, G., Jones, D. B. (1991). Effect of calcium silicate on blast and brown spot intensities and yields of rice. Plant Dis. 75:729732

95. Carson, R. (1991). Silent Spring. Penguin, London

96. Vanlauwe, B. and Giller, K. E. (2006). Popular myths around soil fertility management in Sub-Saharan Africa. Agriculture, Ecosystem and Environment, $116: 34-46$
97. Roy, N. K. (2010). Chemistry of Pesticides. CBS Publishers and Distriibutors PVT Ltd, New Delhi, India, pp346

98. De, A. K. (2012). Environmental Chemistry, New Age International (P) Ltd, Publishers, New Delhi, India pp 319

99. Tully, K., Sullivian, C., Weil, R. and Sanchez, P. (2005). The State of Soil Degradation in Sub-Saharan Africa: Baselines, Trajectories and solutions. Sustainability 2015, 7, 6523-6552

100.Gillespie, W. E., Czarpar, G. F. and Harger, A. G. (2011). Pesticide Fate in the Environment: A Guide for Field Inspectors, Contract-Report 2011-07

101. Borgesen, C. D., Formsgaad, I. S., Kirsten, S., Spliid, N. H. (2015). Fate of Pesticides in Agricultural Soils. DCA Report No 62, June, 2015

102. FAO (2015). Status of the World's Soil ResourcesMain Report Intergovernmental Technical Panel on soils (ITPS). Pp 13-30

103. Ahmad W., Zahir, ShahF., Jamal, M and Ali,Shah, K. (2013). Recovery of organic fertilizer in degraded soil through fertilization and crop rotation. Journal of the Saudi Society of Agricultural Sciences 13, 92-99

104. Bationo, A. Christianson, C. B., Klaij, M. C. (1996). The effect of crop residue and fertilizer use on pearl millet yields in Niger. Fertilizer Research 34:251-258

105. Vanlauwe, B. (2004). Integrated soil fertility management research at TSBF: the framework, the principles and their application. In academy science Publishers. A Bationo (Ed). Managing Nutrient Cycles to Sustain Soil Fertility in sub-Saharan Africa 25-42

106. Akinola, A. A., Alene, A. D., Adeyemo, R. Sanogo, D., Olanrewaju, A. S. (2009). Impacts of balanced nutrient management systems technologies in the northern guinea savanna of Nigeria. Journal of Food, Agriculture and Environment 7:496-504

107. Pypers, P. Sanginga, J. M., Kasereka, B., Walangululu, M., Vanlauwe, B (2012). Increased productivity through ISFM in cassava-legume intercropping systems in the highlands of Sud-kivu, DR, Congo. Field Crop Research, 120:76-85

108. Vanlauwe, B., P. Pypers, E. Birachi, M. Nyagaya, B. van Schagen, J. Huising, E. Ouma, G. Blomme, P. van Asten (2012). Integrated soil fertility management in Central Africa: Experiences of the consortium for improving agriculture-based livelihoods in Central Africa (CIALCA). In: Hershey, C. (eds). Tropical Agriculture Eco-efficiency: from vision to Reality, Cali Colombia: CIAT

109. Vanlauwe, B., Descheemaker, K Giller, K. E., Huising, J., Merckx, R., Nziguheba, G. Wendt, J., Zingore, S. (2014). Integrated soil fertility management in Subsaharan Africa: Unravelling local adaptation, Soil 1:1239-1286 